\title{
Evaluation of Sucrose-Enzyme Relationships among 12 Puerto Rico Sugarcane Varieties
}

\author{
Alex G. Alexander ${ }^{1}$ \\ INTRODUCTION
}

During the past 3 years a major effort has been made at this Station to discover and clarify sucrose-enzyme relationships in sugarcane. These experiments were usually confined to well-established treatments which were known to induce variable sugar levels in cane. No serious attention was given to enzyme roles as they affected the sugar-producing characteristics of different varieties.

More recent studies were specifically centered upon sugar-enzyme relationships among several Puerto Rico varieties. There were two objectives: 1, To discover enzyme-activity trends which would help account for characteristic properties of given varieties, and 2, to find enzyme-activity patterns which would indicate at an early age the sugar-producing capacity of new or test varieties.

\section{MATERIALS AND METHODS}

One-eye cuttings were planted in a medium quartz sand ("silica shot"). ${ }^{2}$ For every variety, 12 to 14 cuttings were planted in each of two glazed, 2gallon pots, and all seedlings were maintained in the greenhouse until harvest at 10 weeks of age. One liter of nutrient solution was supplied to each container every second day, while 1 liter of tapwater was given on alternate days. ${ }^{3}$

Four of the most uniform plants from each variety were selected for harvest at 10 weeks. Both leaf and meristem samples were taken. These were frozen, lyophylized, extracted, and prepared for sugar and enzyme assay in accordance with procedures described earlier (1). ${ }^{4}$

Hydrolytic and oxidative enzymes were studied on the basis of their

${ }^{1}$ Associate Plant Physiologist, Agricultural Experiment Station, University of Puerto Rico, Río Piedras, P.R.

${ }^{2}$ Test varieties included P.R. 900,975,980,1013,1016,1028,1048,1059,1085,1111,1116, and 1117 .

${ }^{3}$ Nutrient concentrations, expressed as milliequivalents per liter, were provided as follows: Nitrate, 10; phosphate, 6; potassium, 5; calcium, 3; magnesium, 2; and sulfate, 2. Microelements, expressed as parts per million, were supplied as follows: Boron, 0.05; copper, 0.02; manganese, 0.50; zinc, 0.05; molybdenum, 0.01; and iron 1.0 .

${ }^{4}$ Italic numbers in parentheses refer to Literature Cited, p. 38. 
earlier relationships found with sugar levels. Phosphatase activity was measured against $\beta$-glycerophosphate. Amylase and invertase were assayed using soluble potato starch and sucrose, respectively. Tyrosinase (polyphenoloxidase) and peroxidase were also measured. Phosphatase procedures were described previously (4), as were those for invertase (5), amylase (6), tyrosinase (8), and peroxidase (7). Enzyme action is expressed as specific activity (activity units per milligram of protein).

Total ketoses were determined by the resorcinol technique of Roe (10), and sucrose by the modification of Cardini et al. (9). Fructose was esti-

TABLE 1.-Sugar and protein contents, in milligrams per gram of dry weight, for leaf and meristem tissues of 12 Puerto Rico sugarcane varieties

\begin{tabular}{|c|c|c|c|c|c|c|c|c|}
\hline \multirow{2}{*}{$\begin{array}{l}\text { Variety } \\
\text { P. R. No. }\end{array}$} & \multicolumn{3}{|c|}{ Leaf sugars- } & \multirow{2}{*}{$\begin{array}{c}\text { Leaf } \\
\text { protein }\end{array}$} & \multicolumn{3}{|c|}{ Meristem sugars- } & \multirow{2}{*}{$\underset{\text { protein }}{\text { Meristem }}$} \\
\hline & $\underset{\text { ketose }}{\text { Total }}$ & Sucrose & Fructose & & $\begin{array}{c}\text { Total } \\
\text { ketose }\end{array}$ & Sucrose & Fructose & \\
\hline 900 & 73.7 & 44.7 & 29.0 & 6.4 & 319.2 & 115.2 & 204.0 & 20.1 \\
\hline 975 & 54.3 & 41.3 & 13.0 & 3.6 & 224.4 & 53.4 & 171.0 & 27.3 \\
\hline 980 & 52.4 & 37.1 & 15.3 & 2.9 & 234.0 & 53.4 & 180.6 & 14.0 \\
\hline 1013 & 72.3 & 48.8 & 24.0 & 3.6 & 234.0 & 78.8 & 163.2 & 41.3 \\
\hline 1016 & 57.0 & 42.5 & 14.5 & 2.7 & 211.8 & 91.2 & 120.6 & 11.8 \\
\hline 1028 & 57.8 & 44.7 & 13.1 & 3.6 & 265.2 & 98.4 & 166.8 & 14.0 \\
\hline 1048 & 83.0 & 69.8 & 13.2 & 3.6 & 291.0 & 123.0 & 168.0 & 12.8 \\
\hline 1059 & 87.8 & 84.9 & 2.9 & 2.0 & 221.3 & 53.6 & 167.7 & 10.9 \\
\hline 1085 & 98.0 & 72.8 & 25.2 & 3.3 & 258.6 & 37.2 & 221.4 & 14.3 \\
\hline 1111 & 84.5 & 58.5 & 26.0 & 2.7 & 282.0 & 141.6 & 140.4 & 10.6 \\
\hline 1116 & 87.0 & 68.1 & 18.9 & 2.7 & 331.8 & 63.6 & 268.2 & 9.9 \\
\hline 1117 & 89.7 & 77.6 & 12.1 & 3.6 & 331.8 & 121.2 & 210.6 & 9.3 \\
\hline Mean & 74.7 & 57.6 & 17.2 & 3.4 & 267.0 & 85.8 & 181.8 & 16.4 \\
\hline
\end{tabular}

mated by subtracting sucrose values from those of total ketose. Protein was measured colorimetrically by the method of Sutherland and coworkers (11).

\section{RESULTS AND DISCUSSION}

Sugar and protein values varied greatly among the 12 varieties (table 1 ), as did enzyme activity (table 2). Leaf fructose varied tenfold and meristem sucrose more than threefold between extreme individuals. Meristem protein ranged from $41.3 \mathrm{mg}$./g. for P.R. 1013 to $9.3 \mathrm{mg}$./g. for P.R. 1117. Among enzymes, leaf amylase gave specific-activity values as low as 92.1 and as high as 500. Meristem invertase, tyrosinase, and peroxidase all exhibited activity extremes far in excess of those expected among an apparently uniform group of plants. 
TABLE 2.-Mean specific-activity values for leaf and meristem enzymes from 12 Puerto Rico varieties of sugarcane ${ }^{1}$

\begin{tabular}{|c|c|c|c|c|c|c|c|c|c|c|c|c|c|}
\hline \multirow{2}{*}{ Variety P.R. No. } & \multicolumn{6}{|c|}{ Values for leaf enzyme- } & \multicolumn{7}{|c|}{ Values for meristem enzyme- } \\
\hline & $\beta$-G-P-ase & ATP-ase & $\begin{array}{c}\text { G-1- } \\
\text { P-ase }\end{array}$ & $\alpha$-Amylase & $\begin{array}{l}\text { Tyro- } \\
\text { sinase }\end{array}$ & Peroxidase & $\beta$-G-P-ase & ATP-ase & G-1-P-ase & $\alpha$-Amylase & Invertase & Tyrosinase & Peroxidase \\
\hline 900 & 15.6 & 18.5 & 5.4 & 92.1 & 0.9 & 50.5 & 10.5 & 11.0 & 4.6 & 96.2 & 1.9 & 1.3 & 46.5 \\
\hline 975 & 26.5 & 31.7 & 7.2 & 206.6 & .7 & 50.0 & 8.5 & 9.2 & 3.5 & 76.5 & 6.0 & 7.5 & 92.9 \\
\hline 980 & 18.9 & 30.9 & 6.6 & 125.4 & 1.0 & 39.3 & 13.9 & 13.9 & 5.3 & 127.5 & 6.8 & 16.5 & 192.7 \\
\hline 1013 & 12.8 & 20.9 & 5.7 & 180.9 & .9 & 28.3 & 4.0 & 4.0 & 1.8 & 47.4 & 1.2 & .3 & 8.7 \\
\hline 1016 & 11.7 & 20.7 & 6.6 & 138.1 & 1.1 & 44.2 & 14.1 & 15.7 & 6.3 & 195.7 & .0 & 19.6 & 57.6 \\
\hline 1028 & 14.7 & 25.7 & 5.6 & 210.0 & 1.2 & 30.0 & 12.1 & 13.9 & 5.6 & 136.7 & .6 & 23.9 & 82.6 \\
\hline 1048 & 18.4 & 27.8 & 6.1 & 277.0 & .8 & 39.2 & 13.0 & 15.7 & 4.9 & 186.0 & .8 & 21.8 & 115.0 \\
\hline 1059 & 13.2 & 23.7 & 8.9 & 500.0 & 2.9 & 30.5 & 19.4 & 19.4 & 8.2 & 209.4 & 9.5 & 47.8 & 221.2 \\
\hline 1085 & 19.2 & 31.8 & 6.9 & 174.5 & .7 & 42.3 & 13.6 & 14.3 & 6.0 & 105.4 & 13.2 & 23.2 & 127.7 \\
\hline 1111 & 16.4 & 27.6 & 6.4 & 185.7 & .7 & 40.2 & 19.6 & 18.9 & 8.1 & 118.1 & 1.3 & 42.2 & 114.4 \\
\hline 1116 & 20.1 & 31.3 & 8.1 & 257.7 & 1.3 & 36.0 & 20.8 & 19.7 & 12.6 & 98.7 & 22.6 & 71.4 & 198.7 \\
\hline 1117 & 14.1 & 23.4 & 6.4 & 124.3 & 1.4 & 60.8 & 18.6 & 15.3 & 9.6 & 165.8 & 2.6 & 27.4 & 82.2 \\
\hline Mean & 16.8 & 26.2 & 6.7 & 206.0 & 1.1 & 40.9 & 14.0 & 14.3 & 63.8 & 130.2 & 5.5 & 25.2 & 111.6 \\
\hline
\end{tabular}

${ }^{1}$ Assays were run in duplicate. Each figure represents the mean of 2 replicates. 


\section{ENZYME ACTIVITY VS. VARIETY CHARACTERISTICS}

In an effort to correlate enzyme activity with specific variety characteristics, the 12 Puerto Rico varieties were ranked with regard to cane ton-

TABLe 3.-Evaluation of 12 Puerto Rico sugarcane varieties as to their performance for tonnage, percent-sugar in cane, and sugar per acre ${ }^{1}$

\begin{tabular}{r|l|l|l}
\hline $\begin{array}{r}\text { Variety } \\
\text { P. R. No. }\end{array}$ & Cane tonnage & $\begin{array}{l}\text { Percent-sugar } \\
\text { in cane }\end{array}$ & Sugar per acre \\
\cline { 2 - 3 } 900 & Low & High & Moderate \\
975 & Moderate & do. & Do. \\
980 & High & Low & High \\
1013 & do. & Moderate & Moderate \\
1016 & Moderate & Low & Do. \\
1028 & do. & High & Do. \\
1048 & do. & Moderate & Do. \\
1059 & do. & Very high & High \\
1085 & High & Moderate & Moderate \\
1111 & Low & High & Do. \\
1116 & High & Low & Low to Moderate \\
1117 & do. & Moderate & Moderate \\
\hline
\end{tabular}

${ }^{1}$ Performance evaluations were made by Mr. F. Méndez Roig, Agronomist at this Station. All varieties are evaluated in accordance with yields from commercial plantings throughout Puerto Rico.

TABLE 4.-Mean specific-activity values for leaf enzymes of 12 sugarcane varieties arbitrarily ranked as to performance for tonnage

\begin{tabular}{l|c|c|c|c|c|c|c}
\hline \multirow{2}{*}{ Performance rating } & \multicolumn{5}{|c|}{ Valves for Leaf enzyme- } & \multirow{2}{*}{ Grand mean } \\
\cline { 2 - 7 } & $\beta$-GP-ase & ATP-ase & G-1-P-ase & $\beta$-Amylase & Tyrosinase & $\begin{array}{c}\text { Per- } \\
\text { osidase }\end{array}$ & \\
\hline Low $^{1}$ & 16.0 & 23.0 & 5.9 & 139 & 0.8 & 45.3 & 38.3 \\
Moderate $^{2}$ & 16.9 & 25.8 & 6.9 & 266 & 1.3 & 38.8 & 59.3 \\
High $^{3}$ & 17.0 & 27.7 & 6.7 & 172 & 1.1 & 41.3 & 44.3 \\
\cline { 2 - 7 } Mean & 16.6 & 25.5 & 6.5 & 192 & 1.1 & 41.8 & 47.3 \\
\hline
\end{tabular}

1 Mean for 2 varieties.

2 Mean for 5 varieties.

${ }^{3}$ Mean for 5 varieties.

nage, percent-sugar in cane, and sugar per acre (table 3 ). Each variety was arbitrarily rated "low", "moderate", or "high" on the basis of past performance throughout Puerto Rico.

Leaf enzymes in general did not show trends related to cane tonnage (table 4). Only amylase seemed to vary among "low"- and "moderate"- 
ranked varieties, having very high activity among the "moderate" group. Activity again dropped for "high" tonnage producers, thus eliminating any trend which would distinguish low from high varieties. Amylase did reveal a clearer trend with regard to percent-sugar in cane (table 5). Here enzyme activity increased steadily from "low" to "high" varieties.

TABLE 5.-Mean specific-activity values for leaf enzymes of 12 sugarcane varieties arbitrarily ranked as to performance for percent-sugar in cane

\begin{tabular}{|c|c|c|c|c|c|c|c|}
\hline \multirow{2}{*}{ Performance rating } & \multicolumn{6}{|c|}{ Values for leaf enzyme- } & \multirow{2}{*}{ Grand mean } \\
\hline & $\beta$-G-P-ase & ATP-ase & G-1-P ase & $\beta$-Amylase & Tyrosinase & $\begin{array}{c}\text { Per- } \\
\text { oxidase }\end{array}$ & \\
\hline Low $^{1}$ & 18.9 & 27.6 & 7.1 & 174 & 1.1 & 39.8 & 44.6 \\
\hline Moderate $^{2}$ & 21.5 & 25.9 & 6.3 & 189 & .9 & 42.7 & 47.7 \\
\hline $\mathrm{High}^{3}$ & 17.3 & 25.4 & 6.7 & 239 & 1.3 & 40.3 & 55.0 \\
\hline Mean & 19.2 & 26.3 & 6.7 & 201 & 1.1 & 40.9 & 49.1 \\
\hline
\end{tabular}

1 Mean for 3 varieties.

${ }^{2}$ Mean for 4 varieties.

${ }^{3}$ Mean for 5 varieties.

TABLE 6.-Mean specific-activity values for leaf enzymes of 12 sugarcane varieties arbitrarily ranked as to performance for percent-sugar per acre

\begin{tabular}{|c|c|c|c|c|c|c|c|}
\hline \multirow{2}{*}{ Performance rating } & \multicolumn{6}{|c|}{ Values for leaf enzyme- } & \multirow{2}{*}{ Grand mean } \\
\hline & $\beta$-GP-ase & ATP-ase & G-1-P-ase & $\beta$-Amylase & Tyrosinase & $\begin{array}{c}\text { Per- } \\
\text { oxidase }\end{array}$ & \\
\hline Low $^{1}$ & 20.1 & 31.3 & 8.1 & 258 & 1.3 & 36.0 & 59.1 \\
\hline Moderate ${ }^{2}$ & 16.6 & 23.1 & 6.3 & 177 & .8 & 42.8 & 44.4 \\
\hline $\mathrm{High}^{3}$ & 16.1 & 27.3 & 7.8 & 313 & 2.0 & 34.9 & 67.0 \\
\hline Mean & 17.6 & 27.2 & 7.4 & 249 & 1.4 & 37.9 & 56.8 \\
\hline
\end{tabular}

${ }^{1}$ Mean for 1 variety.

${ }^{2}$ Mean for 9 varieties.

${ }^{3}$ Mean for 2 varieties.

Data for sugar per acre also revealed marked variations in amylase action (table 6). However, in this instance, amylase was suppressed rather than stimulated among "moderate" varieties. Thus there appears to be an inverse amylase relationship between cane tonnage and sugar per acre, with high enzyme action favoring "moderate" tonnage, and low activity favoring "moderate" sugar production. This is in general agreement with earlier observations that high amylase activity is related to vigorous growth 
TABLE 7.-Mean specific-activity values for meristem enzymes of 12 sugarcane varieties arbitrarily ranked as to cane-tonnage capacity

\begin{tabular}{|c|c|c|c|c|c|c|c|c|}
\hline \multirow{2}{*}{ Performance rating } & \multicolumn{7}{|c|}{ Values for meristem enzyme- } & \multirow{2}{*}{ Grand mean } \\
\hline & $\beta$-G-P-ase & $\begin{array}{l}\text { ATP- } \\
\text { ase }\end{array}$ & $\begin{array}{l}\text { G-1-P- } \\
\text { ase }\end{array}$ & $\begin{array}{c}\beta \text {-Amyl- } \\
\text { ase }\end{array}$ & $\begin{array}{c}\text { Invert- } \\
\text { ase }\end{array}$ & $\begin{array}{c}\text { Tyrosin- } \\
\text { ase }\end{array}$ & $\begin{array}{l}\text { Peroxid- } \\
\text { ase }\end{array}$ & \\
\hline Low $^{1}$ & 14.9 & 14.9 & 6.3 & 107 & 1.6 & 21.8 & 80.5 & 35.3 \\
\hline Moderate $^{2}$ & 13.4 & 14.8 & 5.7 & 161 & 3.4 & 24.1 & 113.9 & 48.0 \\
\hline $\mathrm{High}^{3}$ & 14.2 & 13.4 & 7.1 & 109 & 9.2 & 27.8 & 122.0 & 43.2 \\
\hline Mean & 14.2 & 14.4 & 6.4 & 126 & 4.7 & 24.6 & 105.4 & 42.2 \\
\hline
\end{tabular}

1 Mean for 2 varieties.

${ }^{2}$ Mean for 5 varieties.

${ }^{3}$ Mean for 5 varieties.

TABLE 8.-Mean specific-activity values for meristem enzymes of 12 sugarcane varieties arbitrarily ranked as to percent-sugar in cane

\begin{tabular}{|c|c|c|c|c|c|c|c|c|}
\hline \multirow{2}{*}{ Performance rating } & \multicolumn{7}{|c|}{ Values for meristem enzyme- } & \multirow{2}{*}{ Grand mean } \\
\hline & $\stackrel{\beta \text {-G- }}{\text { P-ase }}$ & $\begin{array}{l}\text { ATP- } \\
\text { ase }\end{array}$ & $\begin{array}{l}\text { G-1-P- } \\
\text { ase }\end{array}$ & $\begin{array}{c}\beta-A m y l- \\
\text { ase }\end{array}$ & $\begin{array}{c}\text { Invert- } \\
\text { ase }\end{array}$ & $\begin{array}{c}\text { Tyrosin- } \\
\text { ase }\end{array}$ & $\begin{array}{c}\text { Peroxid- } \\
\text { ase }\end{array}$ & \\
\hline Low $^{1}$ & 16.3 & 16.4 & 8.1 & 141 & 9.8 & 35.8 & 150 & 53.9 \\
\hline Medium $^{2}$ & 12.3 & 12.3 & 5.6 & 126 & 4.5 & 18.2 & 83 & 37.4 \\
\hline $\mathrm{High}^{3}$ & 13.9 & 14.5 & 6.0 & 127 & 3.8 & 24.5 & 112 & 43.1 \\
\hline Mean & 14.2 & 14.4 & 6.6 & 131 & 6.0 & 26.2 & 115 & 44.8 \\
\hline
\end{tabular}

1 Mean for 3 varieties.

2 Mean for 4 varieties.

3 Mean for 5 varieties.

TABLE 9.-Mean specific-activity values for meristem enzymes of 12 sugarcane varieties arbitrarily ranked as to sugar produced per acre

\begin{tabular}{|c|c|c|c|c|c|c|c|c|}
\hline \multirow{2}{*}{ Performance rating } & \multicolumn{7}{|c|}{ Values for meristem enzyme- } & \multirow{2}{*}{ Grand mean } \\
\hline & $\begin{array}{l}\beta \text {-G- } \\
\text { P-ase }\end{array}$ & $\begin{array}{l}\text { ATP- } \\
\text { ase }\end{array}$ & $\begin{array}{c}\text { G-1- } \\
\text { P-ase }\end{array}$ & $\beta-\underset{\text { ase }}{\beta}$ & Invertase & $\begin{array}{c}\text { Tyrosin- } \\
\text { ase }\end{array}$ & $\begin{array}{c}\text { Per- } \\
\text { oxidase }\end{array}$ & \\
\hline Low $^{1}$ & 20.8 & 19.7 & 12.6 & 99 & 22.6 & 71.4 & 199 & 63.6 \\
\hline Medium ${ }^{2}$ & 12.7 & 13.1 & 5.6 & 125 & 3.1 & 19.7 & 81 & 37.2 \\
\hline $\mathrm{High}^{3}$ & 16.7 & 16.6 & 6.7 & 169 & 8.1 & 32.1 & 207 & 65.2 \\
\hline Mean & 16.7 & 16.5 & 8.3 & 131 & 11.3 & 41.1 & 162 & 55.3 \\
\hline
\end{tabular}

1 Mean for 1 variety.

2 Mean for 9 varieties.

${ }^{3}$ Mean for 2 varieties. 
(1), and supports our theory that a suppression of activity is needed for optimum sugar formation (3). The failure of "high" varieties to show the same trend established between "low" and "moderate" groups is difficult to explain. One can at least say that some sort of change occurs between low and higher ranked groups, and that the arbitrary ranking may not yet fit the actual biochemical trends.

Table 6 also shows that phosphatase activity was higher in the varieties rated as "low" sugar producers. Earlier work at this Station indicates that phosphatases may interfere with sucrose synthesis $(1,2)$, supposedly by breaking down phosphorylated sucrose precursors.

Meristem enzymes generally showed better correlation with variety characteristics than did those of leaves. Both invertase and peroxidase gained consistently as cane tonnage ratings increased from "low" to "high" (table 7). Amylase was again very active among the "moderate" group. With regard to percent-sugar in cane, both tyrosinase and peroxidase were excessively active in the "low" varieties, whereas invertase behaved in an inverse relationship with performance ratings. (table 8). Tyrosinase and peroxidase maintained their discrepancies between "low" and "moderate" varieties when ranked as to sugar per acre (table 9).

Meristem phosphatase was highly active in "low"-rated varieties for both percent-sugar in cane and sugar per acre. Most significant was the relatively low invertase activity among "moderate" and "high" sugar-producing varieties, as compared with excessive invertase action in the "low" variety. Meristem invertase was the single most indicative enzyme measured.

\section{ENZYME ACTIVITY AS AN INDICATOR OF VARIETY PERFORMANCE}

Data such as are presented for invertase in tables 7, 8, and 9 could be helpful in determining variety characteristics with a small amount of plant material. It is obvious that high invertase activity is a characteristic of "high" tonnage varieties and of "low" percent-sugar varieties. Conversely, low invertase activity favors "low" tonnage and "high" percent-sugar. As one might have expected, weak invertase action also appears essential for "high" sucrose per acre.

Meristem sucrose analyses also give reasonable trends for cane tonnage (table 10), and for percent-sugar in cane (table 11). High sucrose content is comparable to a "low" tonnage variety and to a "high" percent-sugar variety. Yet our sucrose values did not show trends that could be correlated with sugar-per-acre values, and the sugar-variety relationships were not nearly as clear as were those based on invertase values.

Whereas the varieties herein described were harvested at 10 weeks of age, sufficient meristem tissue can be taken for enzyme assay as early as 3 weeks. Invertase assay might thus be an excellent tool for evaluating fu- 
ture variety performance at a very early age. We also feel that enzymes such as phosphatases, amylases, and oxidases have shown sufficient promise to warrant further study as indicators of variety performance. In particular,

TABLE 10.-Mean values for leaf sugar and protein, and for meristem sugar and protein, in milligrams per gram of dry weight, from 12 sugarcane varieties ranked arbitrarily as to tonnage capacity

\begin{tabular}{|c|c|c|c|c|c|c|}
\hline \multirow{2}{*}{ Performance rating } & \multicolumn{3}{|c|}{ Leaf- } & \multicolumn{3}{|c|}{ Meristem- } \\
\hline & Sucrose & Fructose & Protein & Sucrose & Fructose & Protein \\
\hline Low $^{1}$ & 51.6 & 27.5 & 4.6 & 128.4 & 172.2 & 15.3 \\
\hline Medium $^{2}$ & 56.6 & 11.3 & 3.1 & 83.9 & 158.8 & 15.4 \\
\hline $\mathrm{High}^{3}$ & 60.9 & 19.1 & 3.2 & 69.2 & 208.8 & 17.8 \\
\hline Mean & 56.4 & 19.3 & 3.6 & 93.8 & 179.9 & 16.2 \\
\hline
\end{tabular}

1 Mean for 2 varieties.

2 Mean for 5 varieties.

${ }^{3}$ Mean for 5 varieties.

TABLE 11.-Mean values for leaf sugars and protein, and for meristem sugars and protein, in milligrams per gram of dry weight, for 12 sugarcane varieties ranked arbitrarily as to percent-sugar in cane

\begin{tabular}{|c|c|c|c|c|c|c|}
\hline \multirow{2}{*}{ Performance rating } & \multicolumn{3}{|c|}{ Leaf- } & \multicolumn{3}{|c|}{ Meristem- } \\
\hline & Sucrose & Fructose & Protein & Sucrose & Fructose & Protein \\
\hline Low $^{1}$ & 49.2 & 16.2 & 2.8 & 69.4 & 189.8 & 11.9 \\
\hline Medium $^{2}$ & 67.3 & 18.6 & 3.5 & 88.1 & 190.8 & 19.4 \\
\hline $\mathrm{High}^{3}$ & 54.8 & 16.8 & 3.7 & 92.4 & 170.0 & 16.6 \\
\hline Mean & 57.1 & 17.2 & 3.3 & 83.3 & 183.5 & 16.0 \\
\hline
\end{tabular}

${ }^{1}$ Mean for 3 varieties.

2 Mean for 4 varieties.

${ }^{3}$ Mean for 5 varieties.

leaf amylase (table 5), and meristem peroxidase (table 7), correlate well with percent-sugar and tonnage characteristics, respectively.

\section{SUMMARY}

Sugar-enzyme relationships were evaluated among 12 Puerto Rico sugarcane varieties. There were two objectives: 1 , To discover enzyme-activity trends which would help account for characteristic variety properties; and 2 , to seek enzyme-activity trends which indicate at an early age the sugarproducing capacity of new or test varieties. All plants were grown in sand 
culture with controlled nutrient supply. Leaf and meristem samples were frozen at 10 weeks for sugar and enzyme assay.

Sugar and enzyme values varied greatly among the 12 varieties, although at harvest all varieties appeared quite similar as to size and vigor. Fructose and sucrose content differed by as much as tenfold among variety extremes. Amylase, invertase, tyrosinase, and peroxidase all exhibited broad differences.

Three variety characteristics were correlated with enzyme action, including cane tonnage, percent-sugar in cane, and sugar per acre. Leaf amylase appeared to affect both cane tonnage and percent-sugar in cane. Leaf phosphatase was particularly active in varieties rated as "low" sugar producers. In meristem, both invertase and peroxidase showed direct correlations with cane tonnage, with activity increasing from low to high as tonnage potential increased. High invertase also correlated with "low" percentsucrose, and with "low" sugar per acre. Both meristem tyrosinase and peroxidase were excessively active among varieties rated as "low" sugar producers.

Since meristematic enzymes can be assayed at a very early age, it was suggested that invertase be employed as an early indicator of sugar-producing potential with test varieties. Peroxidase and amylase also show promise in this respect.

\section{RESUMEN}

Se evaluaron las relaciones que existen entre el azúcar y las enzimas en 12 variedades de caña de azúcar. Dos fueron los objetivos: 1 , Descubrir aquellas tendencias en la actividad enzimática que ayuden a explicar las características peculiares de cada variedad; y 2, buscar aquellas tendencias en la actividad enzimática que indiquen tempranamente la capacidad para producir azúcar de las variedades nuevas o bajo estudio. Todas las plantas se sembraron en arena, regulándose así el suministro de nutrimentos. Se congelaron muestras de la hoja y del meristemo por espacio de 10 semanas para hacer los análisis del azúcar y las enzimas.

Hubo una gran variación en los valores del azúcar y las enzimas entre las 12 variedades, aunque, al cosecharse, todas parecían tener el mismo tamaño y vigor. En casos extremos, el contenido de fructosa y sacarosa llegó a variar hasta 10 veces entre algunas variedades. Hubo también grandes diferencias en el contenido de la amilasa, la invertasa, la tirosinasa y la peroxidasa.

Se correlacionaron con la acción enzimática tres de las características de las variedades, a saber: tonelaje de caña, porcentaje de azúcar en la caña y azúcar por acre. La amilasa de la hoja pareció afectar tanto el tonelaje como el porcentaje de azúcar en la caña. La fostatasa de la hoja fue particular- 
mente activa en aquellas variedades que se consideran como de bajo rendimiento de azúcar. En el meristemo la invertasa y la peroxidasa mostraron una correlación directa con el tonelaje de caña, aumentando la actividad según aumentaba el tonelaje potencial. Un alto nivel de invertasa también estuvo correlacionado con un "bajo" porcentaje de sacarosa y un "bajo" rendimiento de azúcar por acre. La tirosinasa y la peroxidasa del meristemo mostraron una actividad excesiva en aquellas variedades que se consideran de bajo rendimiento de azúcar.

Toda vez que las enzimas meristemáticas pueden analizarse a temprana edad, se sugiere el uso de la invertasa como indicador para probar tempranamente el rendimiento potencial de azúcar de las variedades bajo estudio. También son prometedoras a este respecto la peroxidasa y la amilasa.

\section{LITERATURE CITED}

1. Alexander, A. G., Sucrose-enzyme relationships in immature sugarcane as affected by varying levels of nitrate and potassium supplied in sand culture, J. Agr. Univ. P.R. 48(3): 165-231, 1964.

2. - - Induction of varying sugar levels in leaves of immature sugareane by use of acid phosphatase inhibitors, J. Agr. Univ. P.R. 49(1): 35-59, 1965.

3. - Physiological studies of enzymes catalyzing the synthesis and hydrolysis of sucrose, starch, and phosphorylated hexose in sugarcane, J. Agr. Univ. P.R. $49(1): 60-75,1965$.

4. - Hydrolytic proteins of sugarcane: The acid phosphatases, J. Agr. Univ. P.R. $49(2):$ 204-8, 1965.

5. - Hydrolytic proteins of sugarcane: The Acid Invertases, J. Agr. Univ. P.R. $49(3): 287-307,1965$.

6. - Hydrolytic proteins of sugarcane: Amylase, J. Agr. Univ. P.R. 49(3): 308-24, 1965.

7. - The oxidizing enzymes of sugarcane: Peroxidase, J. Agr. Univ. P.R. 50(1): 36-52, 1966.

8. - - The oxidizing enzymes of sugarcane: Tyrosinase (polyphenol oxidase) $J$. Agr. Univ. P.R. 50(2): 113-30, 1966.

9. Cardini, C. E., Leloir, L. F., and Chiriboga, J., The biosynthesis of sucrose, J. Biol. Chem. 214: 149-55, 1955.

10. Roe, J. R., A colorimetric method for the determination of fructose in blood and urine, J. Biol. Chem. 10\%: 15-22, 1934.

11. Sutherland, E. W., Cori, C. F., Haynes, R., and Olsen, N. S., Purification of the hyperglycemic-glycogenolytic factor from insulin and from gastric mucosa, J. Biol. Chem. 180: 825-37, 1949. 